\title{
A Study on the Undrained Characteristics of Highly plastic soils II: Factors on Strength
}

\author{
Dae-Kyu Kim $^{1^{*}}$ \\ ${ }^{1}$ Department of Civil Engineering, Sangmyung University \\ 고소성토의 비배수 특성에 관한 연구 II: 비배수강도 영향요소 \\ 김대규 $^{1^{*}}$ \\ ${ }^{1}$ 상명대학교 건설시스템공학과
}

\begin{abstract}
The investigation of the undrained strength and the important several undrained geotechnical properties was, in detail, made for highly plastic soils using the field and laboratory testing results. The plastic index, activity, water content, and effective unit weight did not show the notable relationship with both $\mathrm{Su}$ and normalized Su. The OCR, sensitivity, and undrained elastic modulus presented remarkable tendency with normalized Su. It could be concluded that the use of the normalized Su may lead to the reasonable results then the normalized $\mathrm{Su}$ needs further research.
\end{abstract}

요 약 본 연구에서는 고소성토 비배수강도와 주요 특성치들의 관계에 대하여 다양한 현장 및 실내시험 결과를 활 용하여 심층적으로 고찰하였다. 소성지수, 활성도, 함수비 및 유효단위중량 등은 비배수강도 및 정규화 비배수강도 경 우 모두 예상과 달리 특별한 관계를 보이지 않았다. 과압밀비, 예민비 및 비배수탄성계수 등은 정규화 비배수강도와 분명한 관계를 보여주었다. 정규화 비배수강도 방법이 비배수강도와 특성치들의 연구에 크게 도움이 될 것으로 기대 된다.

Key Words : Normalized strength, Highly plastic, Undrained strength, Property

\section{Introduction}

The undrained geotechnical properties are so important that the overall safety of ground and structures might depend on their values specially under undrained condition such as the short-term stability checking for clayey soils[1-4].

In this study, the investigation of the undrained strength and other properties is continued as the second part in the series study on the undrained characteristics for highly plastic soils[5,6].

\section{Discussions of undrained strength}

Fig. 1 to 8 show the relationships between the major geotechnical properties and the undrained strengths, which were obtained from the unconfined(Un), the unconsolidated and undrained triaxial(UU), and the field vane(FV) testings conducted for the highly plastic soils in Gadeokdo, Busan. The water content, OCR, plastic index, activity, void ratio, sensitivity, effective unit weight, and undrained elastic modulus are used as the major properties and the other properties were excluded since they did not show any reasonable results. The other geotechnical profiles and characteristics of the soils including the

The author acknowledges the Dodam Engineering for providing the valuable data.

*Corresponding Author : Dae-Kyu Kim

Tel: +82-41-550-5312 email: daekyu@smu.ac.kr

Received July 26, $2012 \quad$ Revised August 3, 2012

Accepted September 6, 2012 
undarined strengths with depth are described in $\operatorname{Kim}(2012)[6]$.

The water content does not present any remarkable trend with the undrained strengths in Fig. 1 but shows a tendency with the normalized strengths, specially, slightly inverse proportion to the normalized $\mathrm{Su}(\mathrm{UU})$ and $\mathrm{Su}(\mathrm{FV})$. In Fig. 2, the effective unit weight has no notable tendency to both $\mathrm{Su}$ and normalized $\mathrm{Su}$. This is unexpected because the water content and effective unit weight have been thought to have the obvious trend with $\mathrm{Su}$.

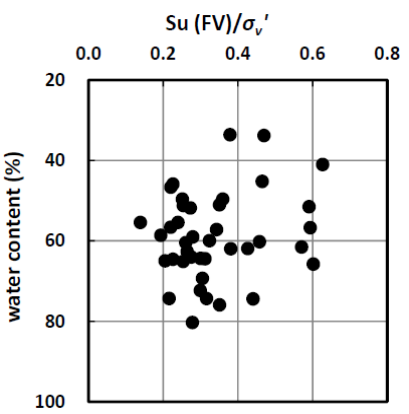

(d) Water content and normalized $\mathrm{Su}(\mathrm{FV})$

[Fig. 1] Water content and normalized $\mathrm{Su}$

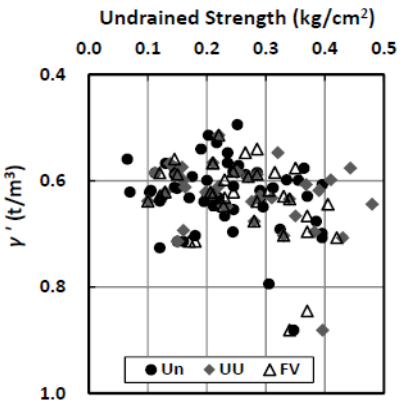

(a) Effective unit weight and normal. Su

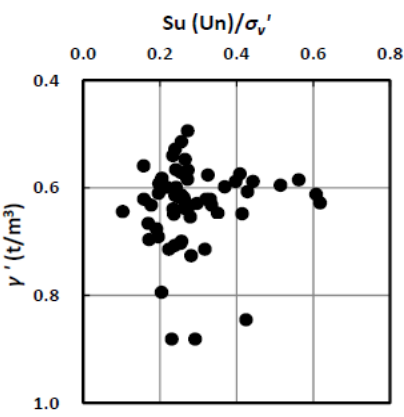

(b) Effective unit weight and normal. $\mathrm{Su}(\mathrm{Un})$

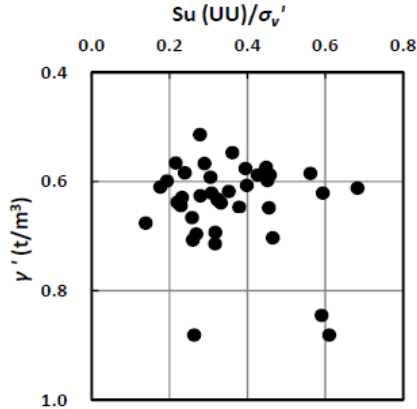

(c) Effective unit weight and normal. Su(UU) 


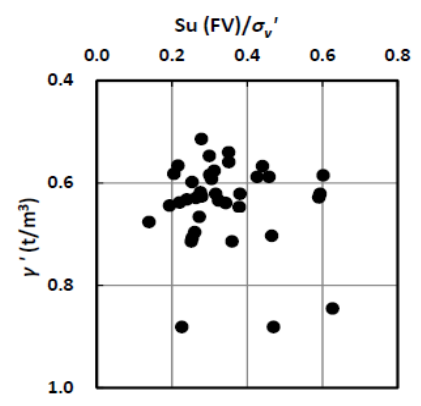

(d) Effective unit weight and normal. $\mathrm{Su}(\mathrm{FV})$

[Fig. 2] Effective unit weight and normal. Su

The OCR has no relation to $\mathrm{Su}$ as shown in Fig. 3 (a); however, the notable and unexpected tendency, which is direct proportional to the normalized $\mathrm{Su}$, is observed in Fig. 1 (b) to (d).

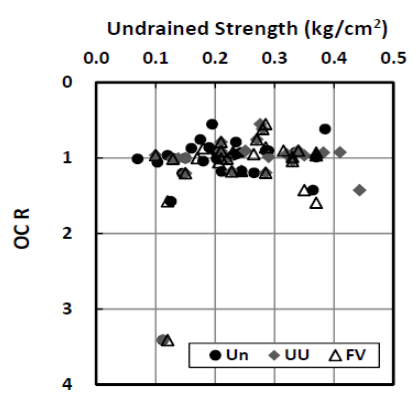

(a) OCR and $\mathrm{Su}$

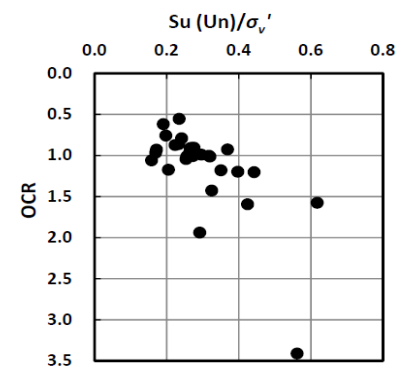

(b) OCR and normalized $\mathrm{Su}(\mathrm{Un})$

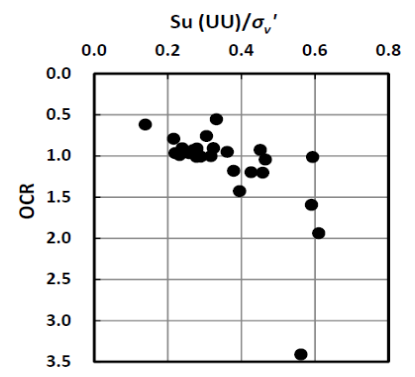

(c) OCR and normalized $\mathrm{Su}(\mathrm{UU})$

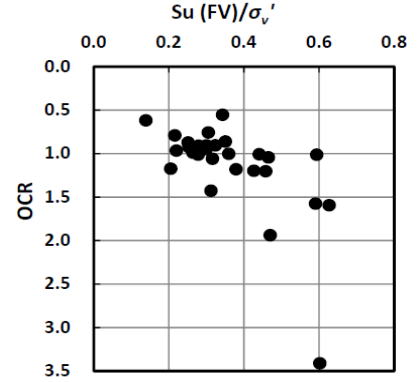

(d) OCR and normalized $\mathrm{Su}(\mathrm{FV})$

[Fig. 3] OCR and normalized Su

The PI has no effect on Su in Fig. 4 (a), on the other hand, it is likely to have inverse proportion relation to the normalized $\mathrm{Su}$, especially $\mathrm{Su}(\mathrm{UU})$ in Fig. 4 (c).

The Activity gives, as expected, similar trend as PI(Fig. 5) since Ac is direct proportional to PI for the soils used in this study[6].

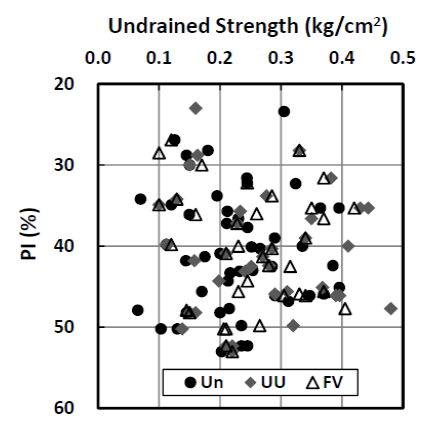

(a) PI and $\mathrm{Su}$ $\mathrm{Su}(\mathrm{Un}) / \sigma_{v}{ }^{\prime}$

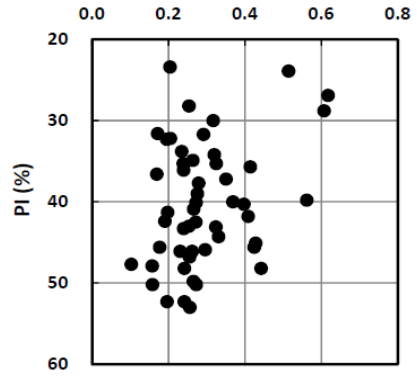

(b) PI and normalized $\mathrm{Su}(\mathrm{Un})$ 


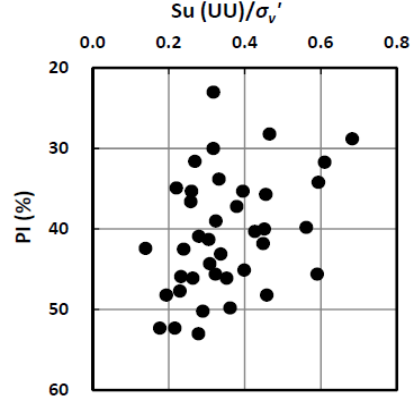

(c) PI and normalized $\mathrm{Su}(\mathrm{UU})$

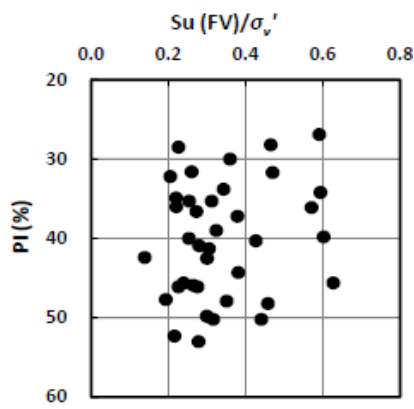

(d) PI and normalized $\mathrm{Su}(\mathrm{FV})$

[Fig. 4] PI and normalized Su

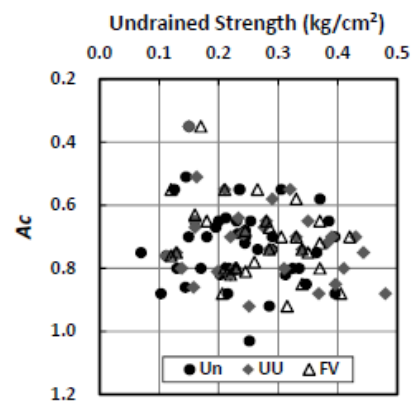

(a) Activity and $\mathrm{Su}$

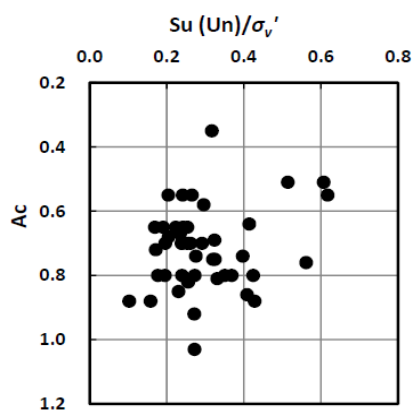

(b) Activity and normalized $\mathrm{Su}(\mathrm{Un})$

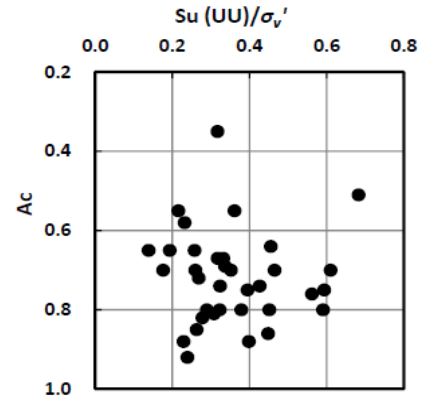

(c) Activity and normalized $\mathrm{Su}(\mathrm{UU})$

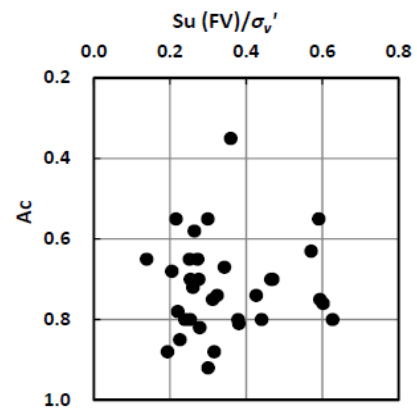

(d) Activity and normalized $\mathrm{Su}(\mathrm{FV})$

[Fig. 5] Activity and normalized Su

It could be found that both $\mathrm{Su}$ and normalized $\mathrm{Su}$ increase with the decrease in the void ratio in Fig. 6. This might be natural because large void ratio implies the soft state leading to low strength.

The sensitivity presents, as shown in Fig. 7, the significant result that it has the direct proportional to the normalized Su. This could be a new area requiring future research since the sensitivity has not yet been successfully related to $\mathrm{Su}$.

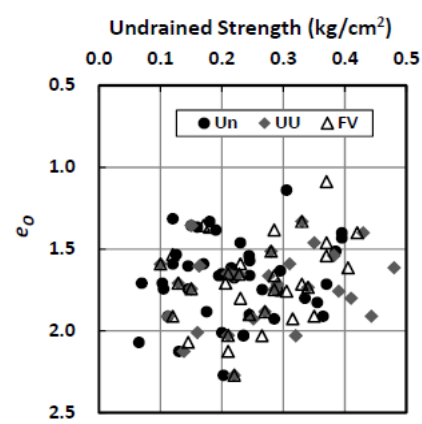

(a) Void ratio and $\mathrm{Su}$ 


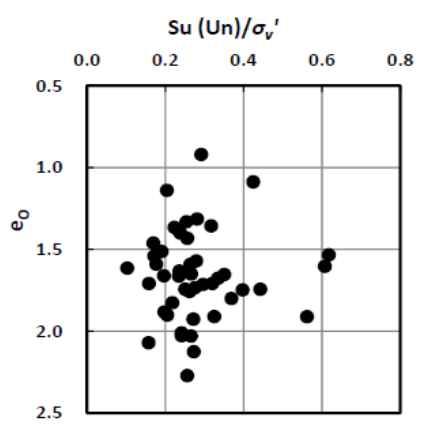

(b) Void ratio and normalized $\mathrm{Su}(\mathrm{Un})$

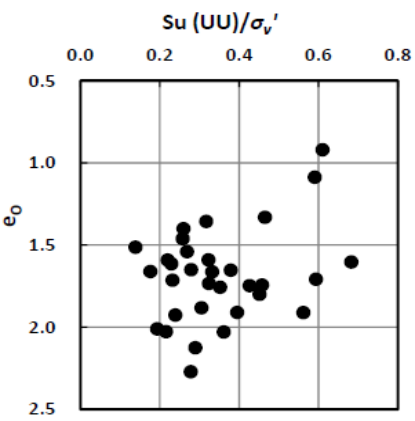

(c) Void ratio and normalized $\mathrm{Su}(\mathrm{UU})$

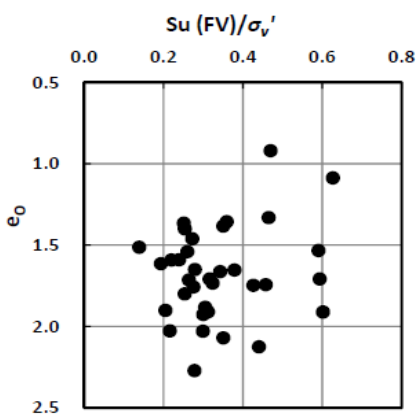

(d) Void ratio and normalized $\mathrm{Su}(\mathrm{FV})$

[Fig. 6] Void ratio and normalized Su

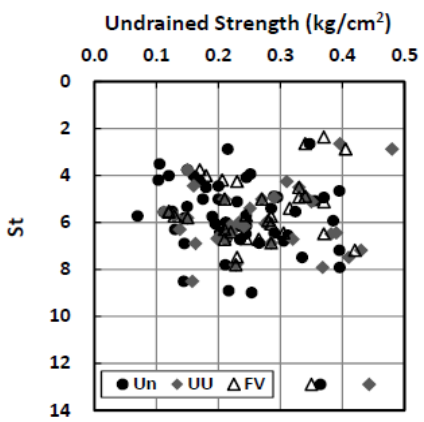

(a) Sensitivity and $\mathrm{Su}$

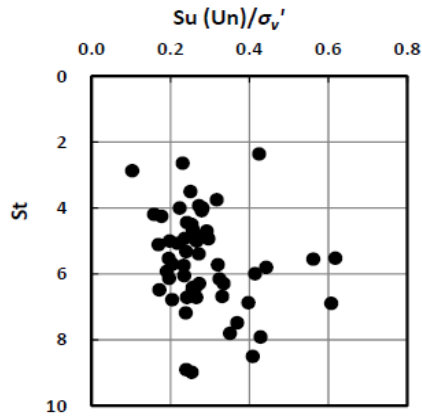

(b) Sensitivity and normalized $\mathrm{Su}(\mathrm{Un})$

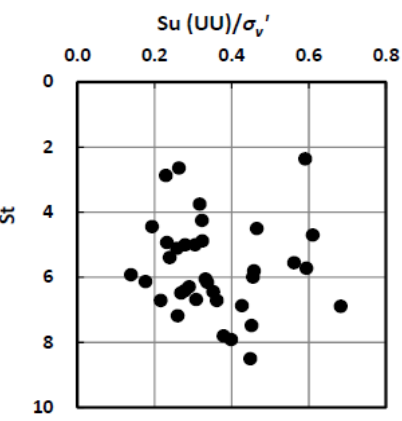

(c) Sensitivity and normalized $\mathrm{Su}(\mathrm{UU})$

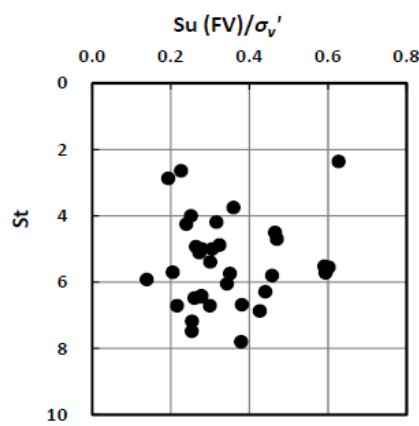

(d) Sensitivity and normalized $\mathrm{Su}(\mathrm{FV})$

[Fig. 7] Sensitivity and normalized Su

The undrained elastic modulus Eu clearly increase with the increase of $\mathrm{Su}$ in Fig. 8 .

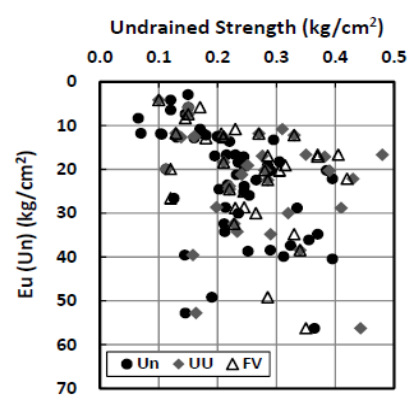

(a) Undrained modulus and $\mathrm{Su}$ 


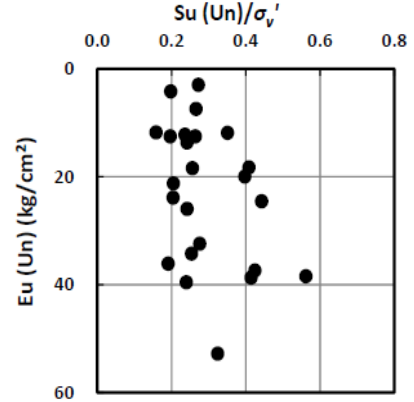

(b) Undrained modulus and normalized $\mathrm{Su}(\mathrm{Un})$

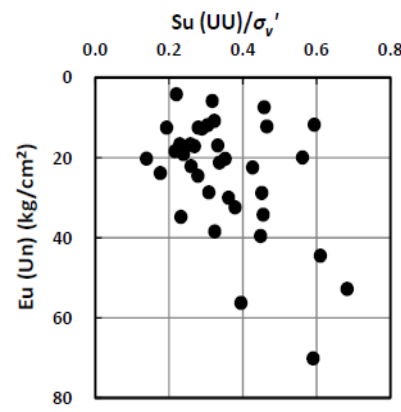

(c) Undrained modulus and normalized $\mathrm{Su}(\mathrm{UU})$

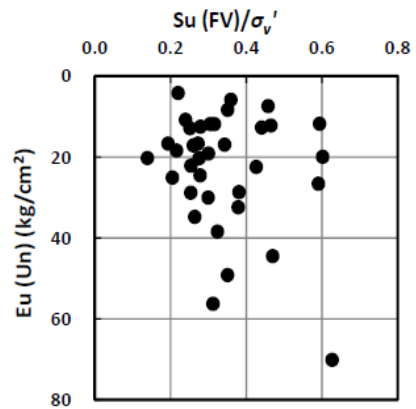

(d) Undrained modulus and normalized $\mathrm{Su}(\mathrm{FV})$

[Fig. 8] Undrained modulus and normalized $\mathrm{Su}$

\section{Conclusions}

The water content, effective unit weight, PI, and activity have, unexpectedly, no remarkable trend with $\mathrm{Su}$ for the highly plastic soils. On the contrary, OCR, sensitivity, and undrained elastic modulus showed clear tendency with normalized Su. It might be thought that the deduction of the empirical relations between normalized $\mathrm{Su}$ and various properties could be possible.

\section{References}

[1] C..D. Kim, S.I. Kim, J.W. Lee, "Estimation of Undrained Shear Strength for Clays using Effective Cone Factor," J. of Korean Society of Geotechnical Engineers, pp. 133-141, Vol. 24, No. 11, 2008.

[2] A. Turan, S. D. Hinchberger, and M. H. El Naggar, "Mechanical characterization of an artificial clay," J. of Geotechnical and geoenvironmental engineering, pp. 280-290, Vol. 135, No. 2, Feb. 2009.

[3] W. Cho and R. J. Finno, "Stress-strain responses of block samples of compressible Chicago glacial clays," J. of Geotechnical and geoenvironmental engineering, pp. 178-188, Vol. 136, No. 1, Jan. 2010.

[4] B F. Schlue, T. Moerz, and S. Kreiter, "Influence of shear rate on undrained vane shear strength of organic harbor mud," J. of Geotechnical and geoenvironmental engineering, pp. 1437-1447, Vol. 136, No. 10, Oct. 2010.

[5] Dodam E\&C, Reports of geotechnical testings for New Harbor Construction in Busan, 2004.

[6] D.K. Kim, "A Study on the undrained characteristics for highly plastic soils I: relations of properties," J. of Korea Academia-Industrial Cooperation Society, in press, 2012.

\section{Dae-Kyu Kim}

[Regular member]

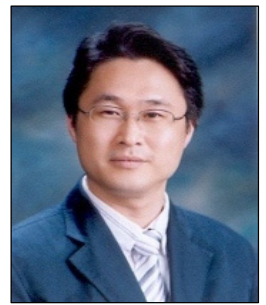

- Dec. 1999 : Louisiana State University, Ph.D.

- Mar. $2002 \sim$ current : Sangmyung University, Dept. of Civil Engineering, Associate Professor

$<$ Research Interests $>$

Geotechnical Engineering, Soils and Foundations, Ground Exploration and Testing, Constitutive Relations, Numerical Analysis, Underground 